\title{
Determination of rheological behaviour of wine lees
}

\author{
Jaromír Lachman ${ }^{1}$, Kazimierz Rutkowski², Petr Trávníček ${ }^{3}$,Tomáš Vitězz , Patrik Burg**, Jan Turan ${ }^{5}$, \\ Petr Junga ${ }^{3}$, and Vladimir Višacki ${ }^{5}$
}

\begin{abstract}
${ }^{1}$ Department of Chemistry, Czech University of Life Sciences in Prague, Kamycka 129, 16521 Praha 6 - Suchdol, Czech Republic ${ }^{2}$ Department of Production and Power Engineering, University of Agriculture, Al. Mickiewicza 21, 31-120 Kraków, Poland ${ }^{3}$ Department of Agricultural, Food and Environmental Engineering, Mendel University in Brno, Zemědělská 1, 61300 Brno, Czech Republic

${ }^{4}$ Department of Horticultural Machinery, Mendel University in Brno, Faculty of Horticulture, Valtická 337, 69144 Lednice, Czech Republic

${ }^{5}$ Department of Agricultural Engineering, University of Novi Sad, Trg Dositeja Obradovića 8, 21000 Novi Sad, Serbia
\end{abstract}

Received November 24, 2014; accepted June 29, 2015

\begin{abstract}
A b s t r a c t. This study deals with the rheological properties of wine lees. Samples of wine lees of the Saint Laurent variety were used in this experiment. The investigated wine lees arose in the process of production red grape wine in 2013 (Czech Republic). At first, the chemical background was determined. The chemical background includes the following chemical parameters: total acidity, $\mathrm{pH}$, alcohol content, reduced sugars, free $\mathrm{SO}_{2}$, total $\mathrm{SO}_{2}$, and volatile acid. In the second phase of the study, physical properties were determined. Specifically, a sample of wine lees was subjected to rheological tests. These tests consisted in determination of dependence of dynamic viscosity on the temperature, hysteresis loop tests, dependence of dynamic viscosity on the time and step-down in the shear rate test. The experiment demonstrated that the dynamic viscosity increased with increased temperature - this phenomenon is caused by thermolabile proteins - and the wine lees has rheopectic behaviour; the degree of rheopexy was found to rise with the increasing temperature.

K e y w o r d s: rheopexy, rheology, wine, products, lees
\end{abstract}

\section{INTRODUCTION}

Given the increasing demands for protection of the environment, wineries look for newer and more economical technologies. These demands are obvious especially in the branch of wine lees processing. The choice of suitable recycling processes with use of new technologies can significantly contribute to environmental protection (Zimmer, 2006).

The grapevine is most commonly grown kind of fruit worldwide. Currently, the area of vineyards is about $7.9 \mathrm{mln}$ ha. Europe holds an approximately $57 \%$ share, which means about $4.5 \mathrm{mln}$ ha of vineyards. According to

*Corresponding author e-mail: patrik.burg@seznam.cz an estimate of the Organisation Internationale de la Vigne et du Vin (OIV, 2009), $66.5 \mathrm{mln}$ t of vine grapes per year is processed worldwide. From this amount, $38 \mathrm{mln} \mathrm{t}$ of vine grapes per year are processed in Europe. Therefore, $1.6 \mathrm{mln} \mathrm{t}$ of wine lees arise only in European conditions every year. From the point of view of waste management, wine lees represents biologically degradable waste produced in the FDM (Food-Drink-Milk) sector. In accordance with basic principles of waste management valid across the European Union, it is necessary to implement waste-free technologies. Wine lees must not be strictly discharged to the municipal wastewater treatment plant. The reason is that the properties of wine lees may cause disruption of biological processes in the wastewater treatment plant.

Generally, rheological properties of beverages are very often discussed in papers of other authors. These are mainly orange and tomato juices (Giner et al., 1996; Ibarz, 1999; Tiziani and Vodovotz, 2005), but many papers deal with grape juices (Arslan et al., 2005; Bayindirli, 1993; Zuritz et al., 2005; ). The basic rheological properties of wine have been evaluated only in a few papers, for example, in the work of Košmerl et al. (2000). It is obvious that knowledge of the thermophysical and chemical properties of wine, especially density and viscosity, are essential for the design and evaluation of industrial processing equipment. This information is necessary for a variety of research and engineering applications over a wide range of concentrations and temperatures (Košmerl et al., 2000). The same applies 
for the properties of wine products such as wine lees, which are not known properly. The aim of this work was to measure the rheological properties of wine lees.

\section{MATERIAL AND METHODS}

Wine lees of the Saint Laurent variety were used in this experiment. The wine lees created solid sediment on the bottom of a fermentation vessel with a volume of $0.4 \mathrm{~m}^{3}$. The wine lees contain live and dead yeast cells, insoluble proteins, dyes, and crystals of calcium tartrate or potassium bitartrate. The content of wine lees depends not only on the sort of the wine but also on the processing method. According to other authors (Marchal et al., 2003), wine lees contain nitrogenous substances $(66.6 \%)$, nitrogenous-free substances (5.4\%), fat (6.6\%), and ash (21.4\%).

There are several methods designed for measurements of the rheological behaviour of substances with different types of measurement geometry such as concentric cylinders, cone and plate or parallel plates (Vítěz and Severa, 2010). An extensive overview of the measurement techniques for rheological testing is given in the paper of Boger et al. (2009). Measurement of rheological properties was performed using this study was performed using an Anton Paar MCR 102 rheometer (Austria) with plate-plate measurement geometry. The diameter of the plate was $50 \mathrm{~mm}$. The gap was set on the value of $0.5 \mathrm{~mm}$. The gap was set with respect to the behaviour of the sample at a higher shear rate, when the liquid starts to leak out of measuring vessel. The constant shear test was performed at a value of the shear rate of $50 \mathrm{~s}^{-1}$. A hysteresis loop test was performed at an interval of a shear rate from 0 to $100 \mathrm{~s}^{-1}$ at temperatures $5,15,25$, and $35^{\circ} \mathrm{C}$.

The rheological experiments were performed with a nondiluted sample and with diluted samples at various rates. The flow curves were modelled using the following model:

Herschel-Bulkley model:

$$
\tau=\tau_{0}+K \dot{\gamma}^{n}(P a),
$$

where: $\tau$ - shear stress $(\mathrm{Pa}), \tau_{0}$ - yield stress $(\mathrm{Pa}), K-$ consistency coefficient (-), $n-$ flow behaviour index $(-), \dot{\gamma}$ - shear rate $\left(\mathrm{s}^{-1}\right)$.

The change in the dynamic viscosity in dependence on temperature was measured at a temperature range of $5-50^{\circ} \mathrm{C}$. The shear rate was constant with a value of $50 \mathrm{~s}^{-1}$.

The density of individual samples was measured using the pycnometer method. For this purpose, pycnometers with a volume of $50 \mathrm{ml}$ and an analytical balance Radwag AS 220/X (Poland) with an accuracy of $0.0001 \mathrm{~g}$ were used. For each sample of the liquid, the density value was determined in three repetitions.

\section{RESULTS AND DISCUSSION}

The measured chemical-physical properties are shown in Table 1. These values are very similar to those obtained in rheological experiments with wines. For example, in the
T a b l e 1. Basic chemical-physical properties of wine lees

\begin{tabular}{lcc}
\hline Parameter & Unit & Value \\
\hline Total acidity & $\mathrm{g} \mathrm{l}^{-1}$ & 5.66 \\
$\mathrm{pH}$ & - & 3.32 \\
Alcohol & $\%$ & 13.4 \\
Reduced sugars & $\mathrm{g} \mathrm{l}^{-1}$ & 4.3 \\
Free $\mathrm{SO}_{2}$ & $\mathrm{mg} \mathrm{l}^{-1}$ & 59.8 \\
Total $\mathrm{SO}_{2}$ & $\mathrm{mg} \mathrm{l}^{-1}$ & 190.6 \\
Volatile acid & $\%$ & 0.39 \\
Density $\left(20^{\circ} \mathrm{C}\right)$ & $\mathrm{kg} \mathrm{m}^{-3}$ & 1018 \\
\hline
\end{tabular}

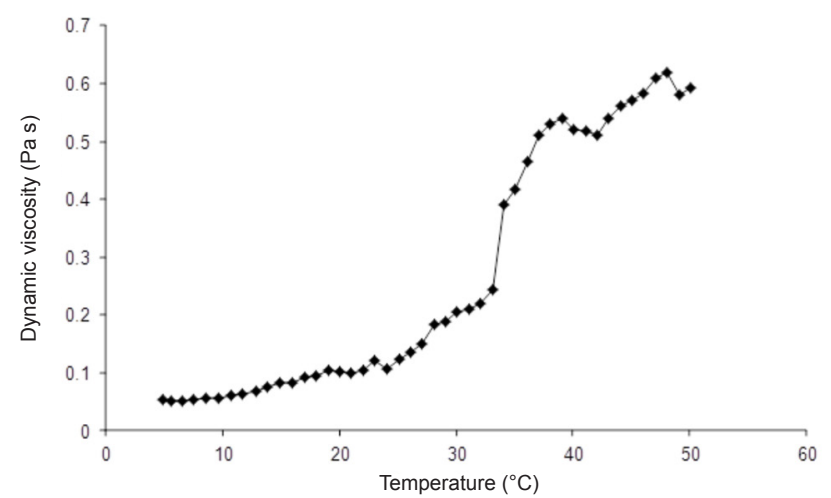

Fig. 1. Dependence of dynamic viscosity on temperature.

paper of Košmerl et al. (2000), the $\mathrm{pH}$ of Merlot wine was 3.50 and total acidity was $5.59 \mathrm{~g} \mathrm{l}^{-1}$. These values are in accordance with data obtained for wine lees. However, the density of wine lees is different. This is caused by the content of organic particles in wine lees. Therefore, the density of wine lees is higher.

The first rheological test consisted in measurement of the dependence of dynamic viscosity on the temperature. This dependence is shown in Fig. 1. From the figure, it is evident that the trend of the curve is atypical. Generally, values of dynamic viscosity decrease with increasing temperature, which is also valid for beverages, especially wine (Košmerl et al., 2000). Different alcoholic beverages exhibit the same trend, for example beer (Severa et al., 2009). However, the trend of the relationship between dynamic viscosity and temperature of wine lees is different. Dynamic viscosity increased with increasing temperature. The breakdown temperature was $33^{\circ} \mathrm{C}$, where the curve steeply increased.

According to Boulton et al. (1996), one of causes of this state can be the dispersive character of wine lees. Wine lees create a dispersive system, consisting of particles with 
various sizes, ie right solutions (particle size: less than $10^{-9} \mathrm{~m}$ ), colloidal solutions (particle size: $10^{-9}-510^{-7} \mathrm{~m}$ ), and suspended particles (particle size more than $10^{-7} \mathrm{~m}$ ). As reported by Zimmer (2006), viscosity of wine lees is mainly influenced by colloids. Colloids perform thermal motion (Brownian motion), gradually diffuse and settle, give rise to osmotic pressure, and participate in formation of gels. Wine lees contain relatively big amounts of thermolabile proteins. When the temperature increases above critical temperature, these proteins coagulate, hence viscosity increases, too (Monteiro et al., 2001).

The comparison showed that the values of dynamic viscosity of wine lees was $0.102 \mathrm{~Pa} \mathrm{~s}^{-1}$ at $20^{\circ} \mathrm{C}$ and the dynamic viscosity of wine at the same temperature was 1.5 $10^{-3} \mathrm{~Pa} \mathrm{~s}^{-1}$ (Košmerl et al., 2000).

The next step was to carry out the hysteresis loop test. The results are shown in Figs 2 and 3. It is evident from both figures that the measured samples are non-Newtonian at the

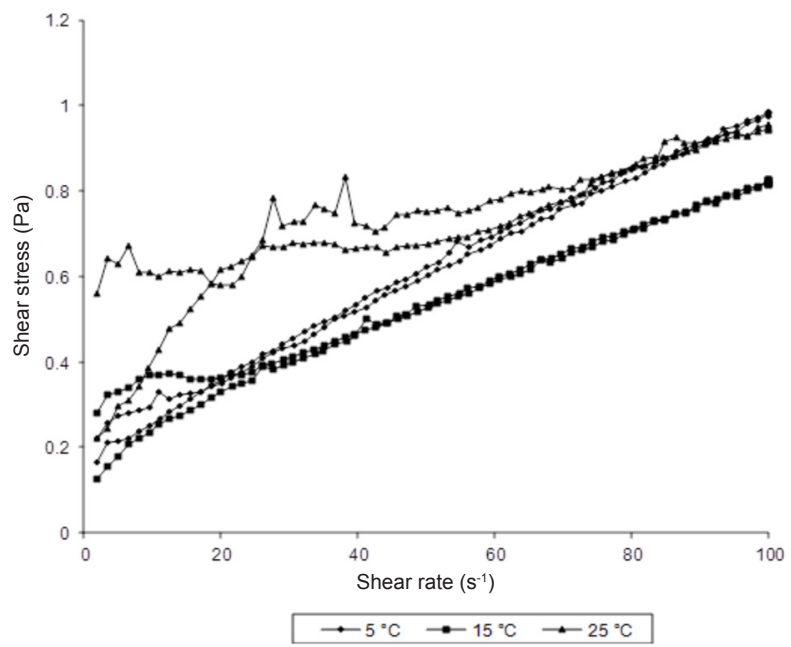

Fig. 2. Hysteresis loop test of wine lees.

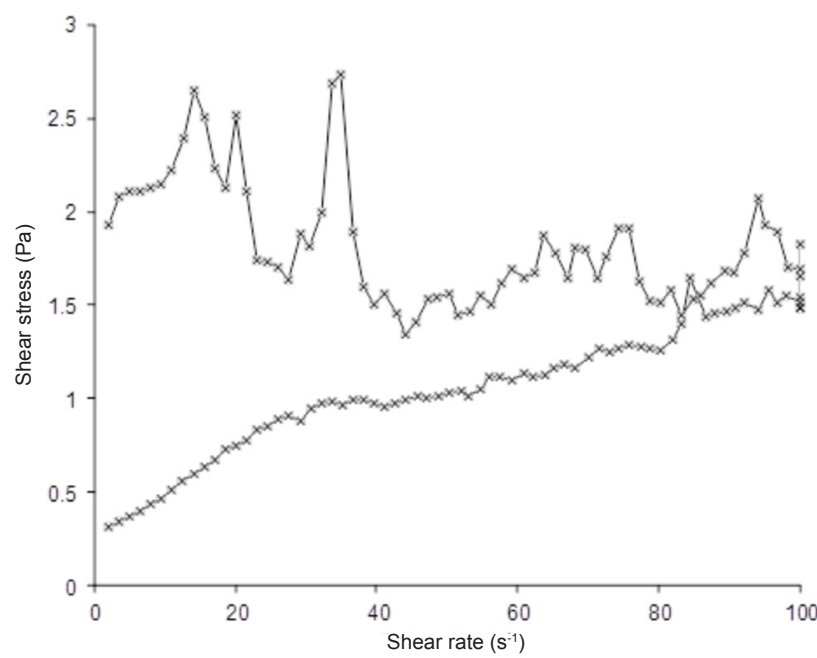

Fig. 3. Hysteresis loop test of wine lees at temperature $35^{\circ} \mathrm{C}$.
T a b l e 2. Hysteresis areas at various temperatures

\begin{tabular}{lcccc}
\hline & \multicolumn{4}{c}{ Temperature $\left({ }^{\circ} \mathrm{C}\right)$} \\
\cline { 2 - 5 } Sample & 5 & 15 & 25 & 35 \\
\hline $\begin{array}{l}\text { Wine lees } \\
\left(\mathrm{Pa} \mathrm{s}^{-1} \mathrm{ml}^{-1}\right)\end{array}$ & 0.64 & -1.87 & -6.20 & -76.39 \\
\hline
\end{tabular}

considered temperature interval. The reason is that the hysteresis loops was created in the process of the tests, where the hysteresis area increased with higher temperature. The values of hysteresis areas are shown in the Table 2.

The value of hysteresis area can be considered as a measure of the degree of thixotropy (Battistoni, 1997). However, the hysteresis area cannot be a sole measure for evaluation of thixotropy or antithixotropy. For example, Baudez (2006) demonstrates that the hysteresis area is simply a consequence of shear localization rather than thixotropic behaviour and its area is closely linked to the apparatus and the data sampling (Baudez, 2006). This means that the loop test is only an approximate test for rheology evaluation of samples. Hence, there is a necessity of development of new types of rheological tests.

From Table 2, it is evident that the biggest hysteresis area was created at the temperature of $35^{\circ} \mathrm{C}$, and in the case of increasing temperature, the hysteresis area increased as well. This is the next sign confirming that, during a temperature change, the structure of substance changes as well.

The data measured in the hysteresis loop test was evaluated with the useoftheHerschel-Bulkleymodel.Thismodel is used for description of the flow curve for material with shear-thinning or shear-thickening behaviour. The results of modelling are shown in Table 3. From the presented data, it is obvious that this model can be used only for low temperature, specifically 5 and $15^{\circ} \mathrm{C}$. At these temperatures, the hysteresis areas were very small and the coefficient of determination was very high. At higher temperatures, the coefficient of determination decreased very quickly and this coefficient was zero at the temperature of $35^{\circ} \mathrm{C}$. The rheological behaviour of substances at various temperatures was different. Based on this knowledge, the sample exhibits shear-thinning or shear-thickening behaviour at low temperature $\left(5\right.$ and $\left.15^{\circ} \mathrm{C}\right)$ and thixotropy or rheopectic behaviour at higher temperature $\left(25\right.$ and $\left.35^{\circ} \mathrm{C}\right)$. A fundamental difference between these types of fluids is that the shear-thinning and shear-thickening behaviour of materials is time-independent rheological behaviour. On the other hand, thixotropy or rheopectic behaviour is time-dependent rheological behaviour. Therefore, the time dependence test was performed to confirm or reject this hypothesis.

The next rheological test deals with time-dependency of the measured substance. This test describes the dependence of viscosity on time. The results of the tests are shown in Figs 4 and 5. The curves of the measured samples exhibited 
T a b l e 3. Rheological parameters of the Herschel-Bulkley mathematical model

\begin{tabular}{cccccc}
\hline Temperature $\left({ }^{\circ} \mathrm{C}\right)$ & $\mathrm{R}^{2}$ & $\begin{array}{c}\text { Standard deviation } \\
(\mathrm{Pa})^{*}\end{array}$ & $\begin{array}{c}\text { Yield stress } \\
(\mathrm{Pa})\end{array}$ & $\mathrm{n}$ & $\mathrm{k}$ \\
\hline 5 & 0.997 & 0.013 & 0.175 & 0.917 & 0.012 \\
15 & 0.969 & 0.032 & 0.129 & 0.717 & 0.025 \\
25 & 0.770 & 0.073 & $* *$ & 0.175 & 0.590 \\
35 & - & - & - & - & - \\
\hline
\end{tabular}

*Relating to shear stress, **makes no sense rheologically, $\mathrm{k}$ - consistency, $\mathrm{n}-$ flow index.

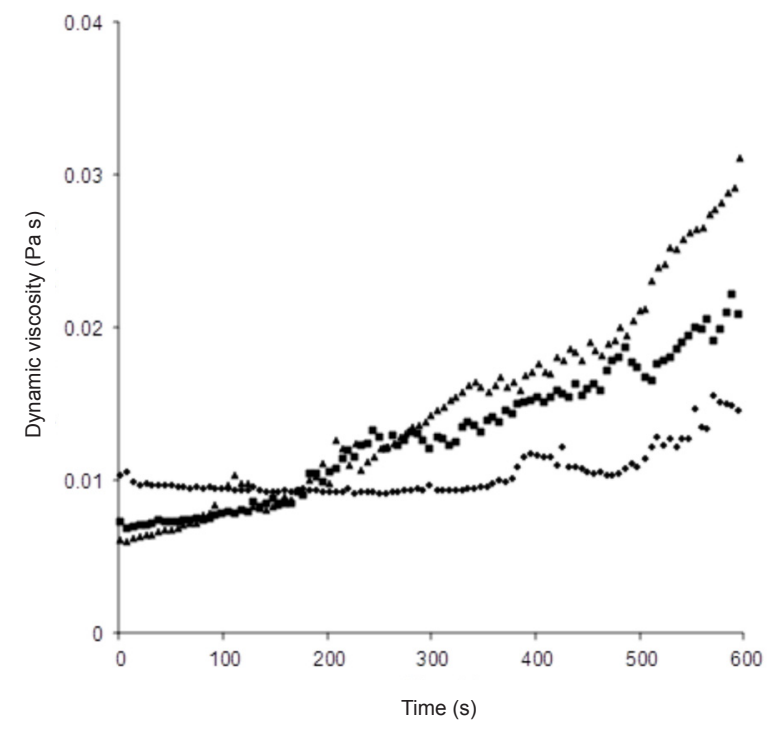

Fig. 4. Dependence of dynamic viscosity of wine lees on time at various temperatures. Explanations as in Fig. 2.

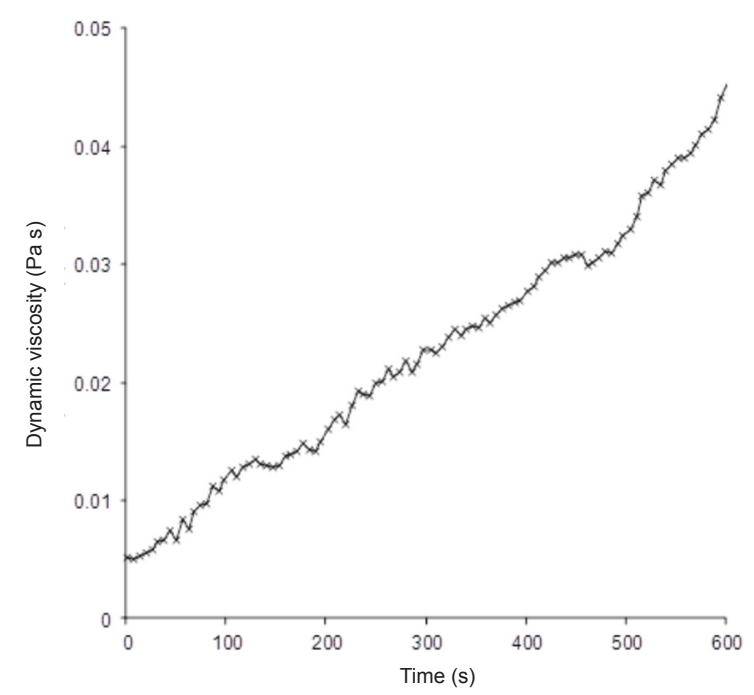

Fig. 5. Dependence of dynamic viscosity of wine lees on time at $35^{\circ} \mathrm{C}$.

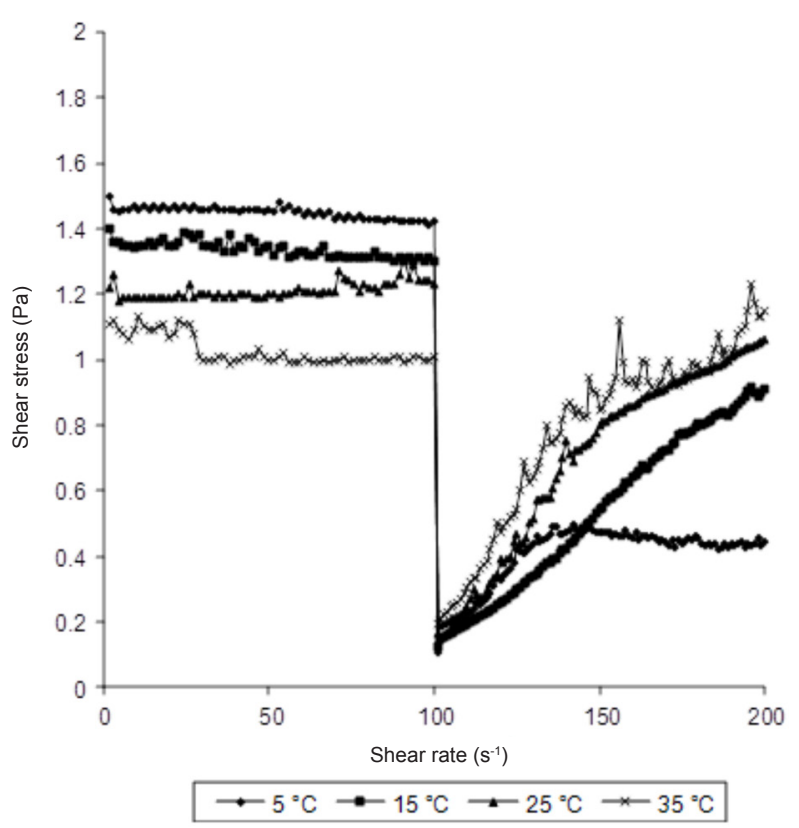

Fig. 6. Step-down in the shear rate test of wine lees at various temperatures.

increasing tendencies during the time at the whole temperature interval considered. This means that the measured samples were time-dependent fluids, and the dynamic viscosity was increasing. This indicates that the particles of the sediment contained in the samples change their structure and agglomerate. Therefore, all the measured samples were regarded as rheopectic fluid at the whole temperature interval considered.

However, there is a possibility that the measured samples of wine lees can be a viscoelastic material. For example, Baudez et al. (2013) reported that raw and anaerobic digested sludge had viscoelastic behaviour and strong similarities with soft-glassy materials and raw and anaerobic digested sludge is a colloidal system similar to wine lees. Hence, the last rheological test was performed. Mewis and Wagner (2009) states that conducting experiment for this purpose a step-down shear rate procedure should be applied. This author also claims that normal viscoelastic fluids, 
irrespective of being in the linear or nonlinear region, would react to such shear history by a monotonic decrease in the stress to a new plateau value. Therefore, during the measurement of the shear stress, the test was stopped at a value of the shear rate of $100 \mathrm{~s}^{-1}$. Subsequently, shear stress was measured at a value of the shear rate of $0 \mathrm{~s}^{-1}$. The results of these tests are shown in Fig. 6. It is obvious that the measured substances had no viscoelastic behaviour - no curves showed a monotonic decrease in the shear stress; on the contrary, all curves showed a monotonic increase in the shear rate. It therefore can be concluded that the measured wine lees exhibited rheopectic behaviour.

\section{CONCLUSIONS}

1. The viscosity of a sample increases when the temperature rises. This unusual situation can be explained by the content of a relatively big amount of thermolabile proteins. When the temperature increases above a critical value, these proteins coagulate and viscosity increases.

2. Hysteresis-loops showed jaggedness of the curves. This is caused by a relatively small gap in measurement geometry when some bigger particles collide with other particles and this leads to a local increase in the shear stress. The relatively small gap was selected, because the liquid component of the sample flows out at bigger values of the shear rate.

3. It is evident from the results of the hysteresis loop tests that the measured samples are non-Newtonian liquid at the temperature interval considered.

4. The apparent viscosity of the sample increased at the constant of the shear rate. This result shows that the tested sample has rheopectic behaviour.

\section{REFERENCES}

Arslan E., Yener M.E., and Esin A., 2005. Rheological characterization of tahin/pekmez (sesame paste/concentrated grape juice) blends. J. Food Eng., 69, 167-172.

Battistoni P., 1997. Pre-treatment, measurement execution procedure and waste characteristics in the rheology of sewage sludges and the digested organic fraction of municipal solid wastes. Water Sci. Technol., 36(11), 33-41.

Baudez J.C., 2006. About peak and loop in sludge rheograms. J. Environ. Manag., 78, 232-239.

Baudez J.C., Gupta R.K., Eshtiaghi N., and Slatter P., 2013. The viscoelastic behaviour of raw and anaerobic digested sludge: Strong similarities with soft-glassy materials. Water Res., 47, 173-180.
Bayindirli L., 1993. Density and viscosity of grape juice as a function of concentration and temperature. J. Food Proces. Preservation, 17, 147-151.

Boger D.V., 2009. Rheology and the resource industries. Chemical Eng. Sci., 64, 4525-4536.

Boulton R., Singleton V.L., Bisson L.F., and Kunkee R.E., 1996. Principles and Practices of Winemaking. Chapman Hall, New York, USA.

Giner J., Ibarz A., Garza S., and Xhian-Quan S., 1996. Rheology of clarified cherry juices. J. Food Eng., 30, 147-154

Ibarz A., 1994. Rheology of clarified fruit juices. III: Orange juices. J. Food Eng., 21 485-494.

Ibarz A., 1999. Rheology of peach dietary fibre suspensions. J. Food Eng., 39(1), 91-99.

Košmerl T., Abramovič H., and Klofutar C., 2000. The rheological properties of Slovenian wines. J. Food Eng., 46, 165-171.

Marchal R., Lallement A., Jeandet P., and Establet G., 2003. Clarificationof muscatmusts using wheat proteins and the flotation technique. J. Agric. Food Chem., 51, 2040-2048.

Mewis J. and Wagner N.J., 2009. Thixotropy. Advanced in Colloid Interface Sci., 147-149, 214-227.

Monteiro S., Piçarra-Pereira M.A., Mesquita P.R., Loureiro V.B., Teixeira A.R., and Ferreira. R.B., 2001. The wide diversity of structurally similar wine proteins. J. Agric. Food Chem., 49, 3999-4010.

Organisation Internetionale de la Vignet et du Vin (OIV), 2009. Internationaler Kodex der önologischen Praxis (in German), 2nd Ed. 160.

Tiziani S. and Vodovotz Y., 2005. Rheological effects of soy protein addition to tomato juice. Food Hydrocolloids, 19, 45-52.

Severa L., Los J., Nedomová Š., and Buchar J., 2009. Influence of temperature on the dynamic viscosity black beer. In: Quality and the Production Efficiency of Regional and Small Breweries (in Czech). Mendel University in Brno Press, Brno, Czech Republic.

Vítěz T. and Severa, L., 2010. On the rheological characteristics of sewage sludge. Acta Univ. Agric. et Silvic. Mendel, Brun, 58, 287-294.

Zimmer E., 2006. Zusammensetzung, physikalische Eigenschaften und Entstehung der Trubpartikel in naturtrüben Apfelsäften sowie Einfluss von Herstellungstechnologie und Rohware auf Trübung und Trübungsstabilität (in German). Dissertation der Justus-Liebig Universität, Gießen.

Zuritz C.A., Muñoz Puntes E., Mathey H.H., Gasco'na A., Rubio L.A., Carullo C.A., Chernikoff R.E., and Cabeza M.S., 2005. Density, viscosity and coefficient of thermal expansion of clear grape juice at different soluble solid concentrations and temperatures. J. Food Eng., 71, 143-149. 